\title{
Effect of Lineament and Drainage Orientation on Groundwater Potential of Moro Area Central Kwara State Nigeria
}

\author{
M.A. Bawallah",*, M.O. Ofomola², S.O. Ilugbo1, A.O. Aina3, S.O. Olaogun', \\ K.O. Olayiwola ${ }^{4}$ and D.R. Awoniran ${ }^{4}$
}

\author{
'Department of Applied Geophysics, Federal University of Technology, Akure, Ondo \\ State, Nigeria \\ 2Department of Physics, Delta State University, Abraka, Delta State, Nigeria \\ ${ }^{3}$ Department of Geological, Chemical and Physical Science, Kwara State University \\ Malete, Nigeria \\ ${ }^{4}$ Department of Remote Sensing and GIS, Federal University of Technology, Akure, \\ Ondo State, Nigeria
}

\begin{abstract}
Article Type: Article
Article Citation: M.A. Bawallah, M.0. Ofomola, S.0. Ilugbo, A.O. Aina, S.O. Olaogun, K.0. Olayiwola and D.R. Awoniran. Effect of Lineament and drainage orientation on groundwater potential of Moro Area Central Kwara State Nigeria. Indian Journal of Science and Technology. 2020; 13(10), 1124-1134. D0l: 10.17485/ijst/2020/ v013i10/147567
\end{abstract}

Received date: September 17, 2019

Accepted date: November 13, 2019

*Author for correspondence: M.A. Bawallah musabawallah@ gmail.com 9 Department of Applied Geophysics, Federal University of Technology, Akure, Ondo State, Nigeria

\begin{abstract}
Objectives: This study investigates the effect of lineaments and surface water flow direction on groundwater prospect of Moro area of Central Kwara, Nigeria using landsat imagery, drainage pattern, and groundwater potential map in a bid to determine the causes of persistent borehole failure and low yield. The study involved the extraction of lineaments from Landsat Thematic Mapper (TM) satellite imagery and construction of drainage network. The geographic information system (GIS) environment was effectively used for the lineament analysis. The lineaments and drainage system were superimposed on an already existing groundwater potential map generated from vertical electrical sounding data in the area. The lineament map showed that most of the structures are found in the north-eastern and south-western parts while other areas were characterized by scanty and no lineaments (structures). The superimposition of lineaments on drainage patterns showed that they are not structurally controlled. The results obtained from the superimposed lineament and drainage system correlates reasonably with the groundwater potential map. The groundwater potential in the area was therefore characterized using the degree of interaction between the lineament and drainage system. The north-western, central and parts of the southern region of the study area were demarcated as having high groundwater potential while others are characterized with moderate potential except a small portion in the south-western part which is of low groundwater potential. It is inferred that the weak lineaments and drainage pattern interaction
\end{abstract}


is responsible for the low recharge rate of aquifers resulting in low groundwater potential in some part of the study area.

Keywords: Lineament, Drainage, Groundwater Potential, Moro Area, Orientation.

\section{Introduction}

Water has ever been the sustainer of life. A community with no access to stream water will go for hand dug well or borehole. Groundwater occurs in the cracks and holes that exist in the rock units. Knowing that groundwater potential of a basement complex terrain is determined by a complex interrelationship between the geology, post-emplacement, tectonic history, weathering processes and depth of occurrence, composition of the weathered layer, aquifer types, groundwater flow pattern, climate, recharge and discharge processes [1], lineament and drainage orientation may have a significant effect on groundwater potential of an area [2]. Effectual method for mapping of fracture zones is based on lineament indices generated from air-photos and from satellite imagery [3]. However, the availability and usage of groundwater in an area is dependent on the hydrogeological factors such as rainfall and run-off, geological factors such as textures and structures of the sub-surface formations. The groundwater accumulation and quantity yield is related to the permeability and porosity of the reservoir rock [4]. The challenge is traced down to several factors and it is expedient to evaluate the relationship between the lineament, topography and surface water flow direction; as they will in no doubt contribute to aquifer productivity in a typical basement complex terrain. Several $[5,2]$ have define lineaments as extended and comprehensive mappable linear or curvilinear features of a surface whose parts are in a straight or nearly straight relationships that may be the manifestations of folds, fractures or faults in the subsurface. An aquifer can only be productive if the pore spaces and/or fractures are associated giving rise to an increased porosity and permeability of the aquifer. The major source of water that feed the openings in a rock unit are from any kind of precipitation or stream; and considerable degree of porosity and permeability might be generated in the rocks through the processes of fracturing and weathering [6]. The interconnectivity of fractures is assumed to be greater in the direction parallel to the principal stress field [3]. The drainage orientation system and its connection with the aquifer may have a significant impact on the efficiency and yield of an aquifer. From previous studies, Kwara central is characterized by low groundwater potential and this is a major challenge facing the residents of this area [7]. In unravelling the causes of low yield of some boreholes in the area, the inter-relationship between surface water and groundwater cannot be ignored and needed to be evaluated. This is by critically studying the communication between surface water flow direction and lineament (possibly fissures) in the study area. The aim of this research, therefore, is to carry out hydrogeophysical studies of Moro area, Central Kwara State Nigeria for groundwater evaluation and yield prediction. 


\section{Description and Geology of the Study Area}

The study area covers four local government area of Kwara State, Nigeria, including Moro, Asa, Ilorin West, and Ilorin East and is situated within latitude $8^{\circ} 31^{\prime} 0^{\prime \prime} \mathrm{N}$ to $8^{\circ} 43^{\prime \prime} 0^{\prime \prime \prime} \mathrm{N}$ and longitude $4^{\circ} 28^{\prime} 00^{\prime \prime} \mathrm{N}$ to $4^{\circ} 34^{\prime} 0^{\prime \prime} \mathrm{E}$. Moro local government is to the North and North-eastern part, Asa to the West, and Ilorin West and East to the Southern part of the study area (Figure 1). The topography is generally undulating with some areas having hilly ridges and gentle steeps. The area is classified under tropical climate, comprising of the wet and dry distinct seasons. The wet/rainy season starts in April and ends in October while the dry season runs from October to April. The mean annual rainfall is about 1333.66 $\mathrm{mm}$. The temperature ranges between 23 and $32{ }^{\circ} \mathrm{C}$. The mean annual evapotranspiration falls between $1500 \mathrm{~mm}$ and $1750 \mathrm{~mm}$ [8]. The vegetation is basically Savannah (Guinea) interspersed with tropical forest remnants. The study area belongs to the south-western crystalline rock of Precambrian Basement Complex of Nigeria [9]. The geology is made up of Granite-Gneiss in the eastern part, Biotite Hornblende Granite in the North-eastern part and extended to the Eastern part, Quartzite to the small area in the North-eastern part, Porphroblastic Gneiss in the north and extended towards the central part of the study area (Figure 2). The major part of the study area from the southern region, spreading through the central area and to the larger area in the northern flank towards the Northeast is covered with Migmatite.

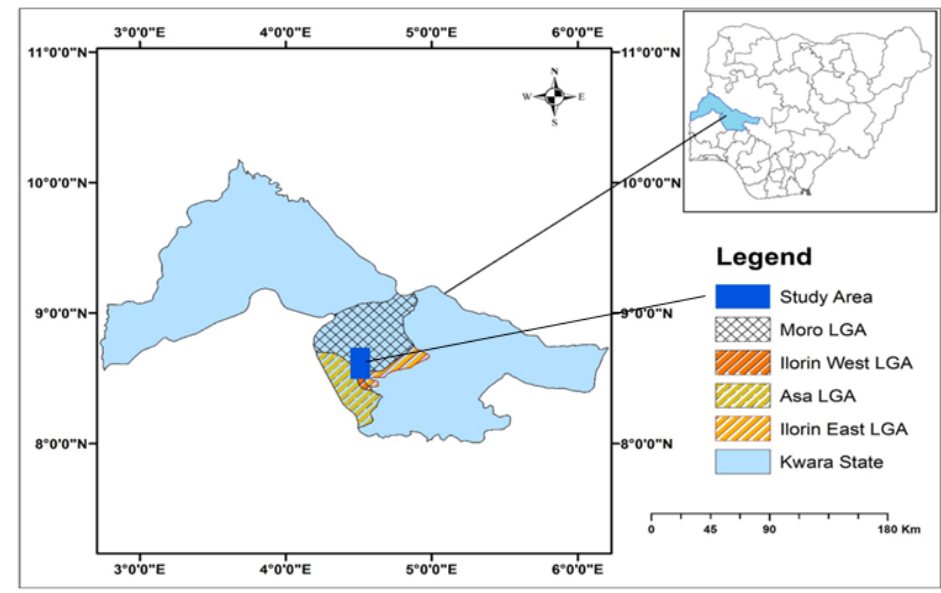

FIGURE 1. Location map of the study area.

\section{Methodology}

Data for remote sensing, drainage pattern, and existing groundwater prospect maps were used for the study. In order to filter out "false" or non-existent lineaments and to determine areas that are prone to contain areas of geotectonic or geomorphologic activity that may influence groundwater flow behavior, the coincidence analysis method was used. Lineaments considered "coincident" are those that were interpreted five or more times. 


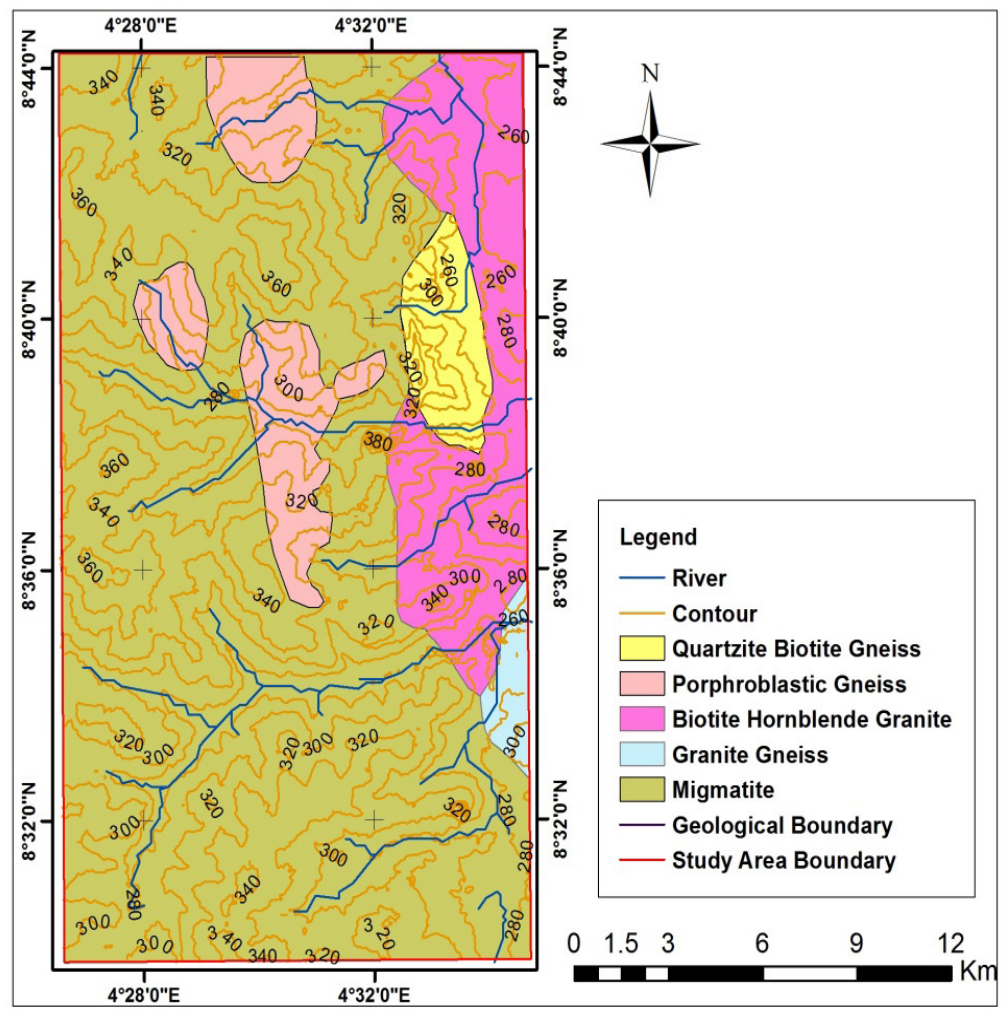

FIGURE 2. Modified geological map of the study area.

The used Landsat 7 Thematic Mapper Imagery was downloaded with path 189 and row 055 of the year 2006 from the Global Cover Facility homepage (http://glcf.umiacs.umd. edu/index.shtml). "ENVI" 4.5, “Geomatical” pcl, and "ArcGIS” 10.1 software were used for digital image processing and automatic lineament extraction from the satellite imageries. Rose diagram was also generated for the lineaments in the study area using the Georient software program. Automatic extraction of lineament is better than the manual lineament because of its ability to uniformly extract the different images; complex but subjective method, absolutely depends on the intricacy of the research area and slight effect of human subjection [2]. Identification and mapping of targets of lineaments required digital processing of the satellite imageries [10]. The extraction and analysis of lineaments from digitally enhanced imageries can provide base sources for regional, structural, and tectonic studies [11-12]. Drainage pattern was digitized from topographical map using ArcGIS 10.1 software.

The Lineament map was superimposed on the drainage pattern in order to determine the interrelationship between the structural trends and the surface water flow direction. The existing groundwater potential map of the study area was determined using vertical electrical sounding data [7]. The superposition of lineaments on drainage pattern was correlated with the groundwater potential map in order to ascertain the effect of lineaments and drainage orientation on groundwater potential. 


\section{Results and Discussion}

\subsection{Remote Sensing}

\subsubsection{Lineaments}

The obtained results from the satellite image interpretation (Figure 3) are discussed to reveal the applicability of remote sensing in the mapping and analysis of lineament with a view to delineating zones that are suitable for groundwater development in the study area. The lineament map generated from the study area was used as a confirmatory tool on the possible reasons for general low groundwater yield in the area. The map provides necessary information, for a better understanding of how the interrelationship could be a major contributing factor to the groundwater prospect of the area. The lineaments are oriented in the north-eastern and south-western direction, especially for the macro structures which account for about 2 to $4 \%$ of the structures. These macro structures occur mainly at the north-eastern end to the south-eastern part of the study area with length of about 5-18 $\mathrm{km}$. The micro lineaments account for about 5 to $10 \%$ of the total structures and they are oriented in north-eastern and south-western direction with length of about $800 \mathrm{~m}$ to $5 \mathrm{~km}$, while mini structures are multi-directional, and some found in the west-eastern direction, others are in the north-eastern and south-western directions. They account for about 80 to $84 \%$ of the total structures with length of about $200 \mathrm{~m}$ to $3 \mathrm{~km}$.

\subsection{Drainage}

Drainage is a system that is responsible for collecting and transporting surface water from a source to another end, either near or far distance. Drainage pattern reflects surface

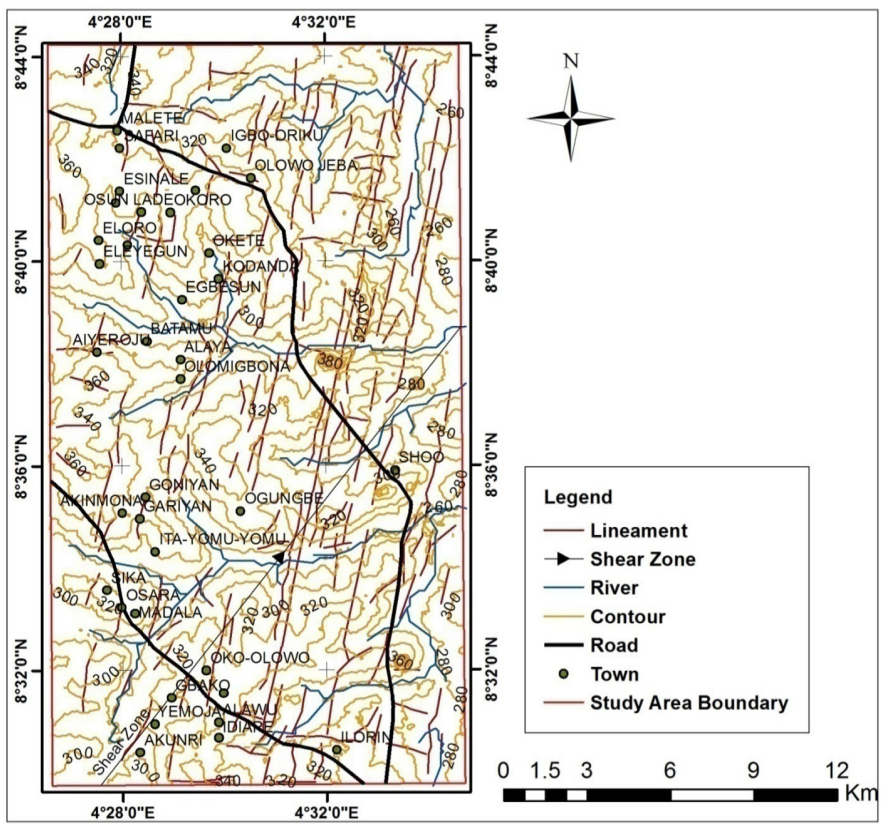

FIGURE 3. Lineament map of the study area. 
characteristics as well as subsurface formation. Drainage density and type of drainage gives information related to runoff, infiltration, relief, and permeability [13]. Dendritic drainage indicates homogenous rocks, the trellis, rectangular and parallel drainage patterns indicate structural and lithological controls. The coarse drainage texture is an indication of highly porous and permeable rock formations while fine drainage texture is more predominant in less pervious formations.

The drainage pattern was determined from the lineament map and this showed that most of the streams and river tributaries follow the east to west directions, which is different from the lineament (geologic structures). This is an indication that the streams are not structurally controlled.

\subsection{Groundwater Potential}

Secondary vertical electrical sounding (VES) data were employed to produce groundwater potential map (Figure 4) of the study area with a view to correlating the intersection of lineaments on drainage pattern. Borehole data and hand pump well across the study area were used to validate the accuracy of the groundwater potential map. The validation was carried out by superimposing the boreholes and hand pump well data on the groundwater potential map as shown in Figure 4. The groundwater potential map is classified into three (3) region with high groundwater potential in the northern, north western, south western and small closure at the southern part of the area. Also, a larger part of the area showed moderate groundwater potential which include the northern, north western, middle eastern, and part of the south western section. The other parts of the study area are characterized by low groundwater potential as observed in the south western end [7].

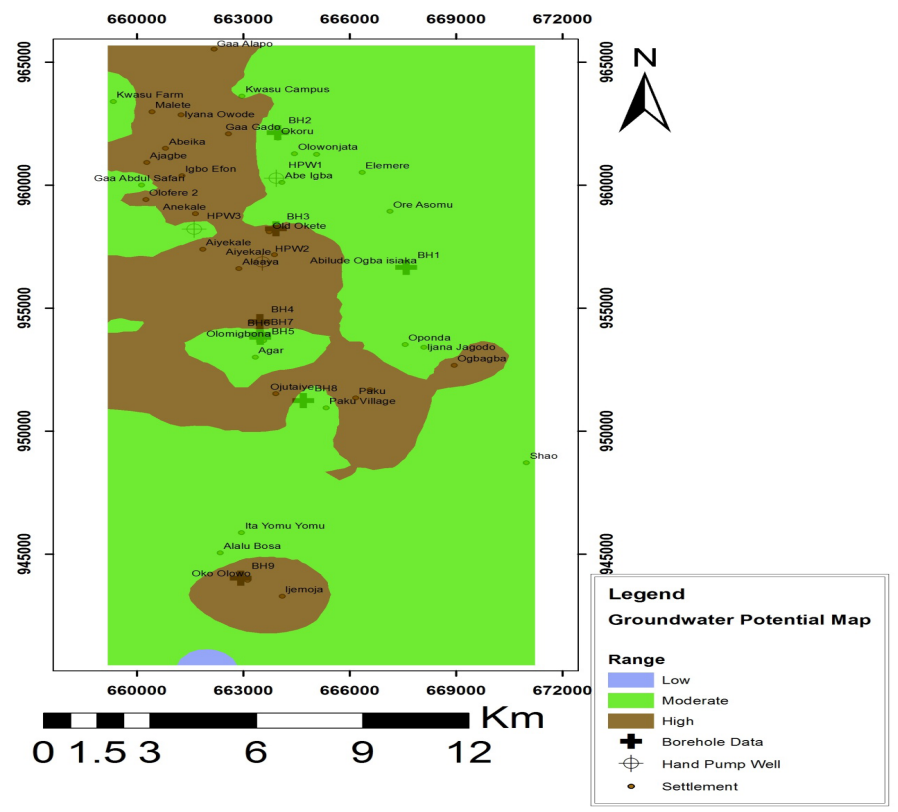

FIGURE 4. Groundwater potential map of the study area [7]. 


\subsection{Validation of Groundwater Potential Map}

Pumping test results from boreholes and hand pump wells drilled across the study area were used to authenticate the correctness of the groundwater potential map and consequently of the employed methodology. The validation was carried out by superimposing the boreholes on the groundwater potential map and the actual yield of each borehole was then compared with the expected yield of its location on the groundwater potential map. Table 1 shows the coincidence (agreement) between the actual and the expected yields and the success rate of the prediction was estimated as follows:

TABLE 1. Validation of the groundwater potential map

\begin{tabular}{lll}
\hline Locations & Expected yield description & Remarks \\
\hline Abilude & Productive BH /medium yield & Coincide \\
Abe Igba & Productive hand pump/low yield & Not coincide \\
Okoru 3 & Failed borehole & Not coincide \\
Okete & Not productive borehole & Not coincide \\
Tegbesun & Hand pump low yield & Coincide \\
Normadic schl. Aiyekale & Abortive hand pump & Coincide \\
Alaaya Basida & Productive borehole & Coincide \\
Olomigbona 1 & Failed borehole & Coincide \\
Olomigbona 2 & Failed borehole & Coincide \\
Olomigbona 3 & Failed borehole & Coincide \\
Ojutaiye 2 Gaa Sanni & Productive borehole & Coincide \\
& High yield borehole & \\
Okoolowo/Aiyelabowo & High yield borehole & Coincide \\
\hline
\end{tabular}

Total number of hand pump wells $=3$

Number of hand pump wells where the expected the actual yield classifications coincide $=2$

Number of hand pump well where the expected the actual yield classifications did not coincide $=1$.

Success rate (accuracy) of the groundwater potential map is $=2 / 3 \times 100=67 \%$

Total number of boreholes $=9$

Number of borehole where the expected and the actual yield classification coincide $=7$

Number of boreholes where the expected and the actual yield classification did not coincide $=2$

Success rate (accuracy) of the groundwater potential map is $=7 / 9 \times 100=78 \%$

Success rate (accuracy) of the groundwater potential for both borehole and wells data is $=9 / 12 \times 100=75 \%$

The prediction success rate (accuracy) obtained showed that the proposed method in this study is capable of producing reliable and accurate results.

\subsection{Superimposition of Lineaments on Drainage Pattern}

Figure 5 illustrates the superimposition of lineaments on drainage pattern. The streams do not have an effective intersection with the lineaments (structures) and therefore this will 
have an effect on the aquifer yield and productivity. Since they are not actively recharging the aquifers, large number of the boreholes will fail or at least experience very low/low yield during the dry season. The map also shows that the streams are not structurally controlled and therefore they are expected to be affected by seasonal variations. Hence, they tend to dry up at the peak of the dry season. The hydrogeological significance and effect of this development arising from an ineffective communications between lineaments and drainage pattern which could recharge aquifer within the study area is significant. Lineaments and drainage pattern play an interdependent role in the process of recharge; hence, it remains a major factor to be considered in aquifer productivity. Therefore, the effect of structural trends and their inter-relationship with flow direction of surface water in the study area cannot be farfetched. The study also revealed that the lineaments in the area were constrained to northeast and south-western direction while the stream and rivers are flowing nearly east-west direction, which implies lack of effective communication between the structures and a major source of recharge (surface water) as posited by Ref. [2].

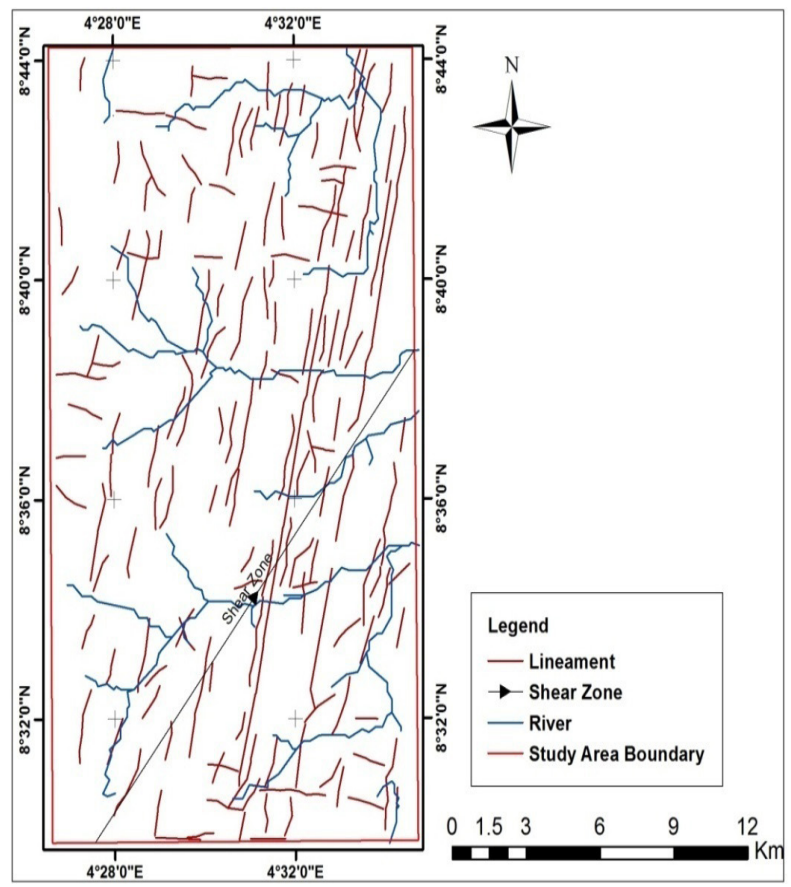

FIGURE 5. Superimposition of lineament on drainage pattern map of the study area.

\subsection{Correlation of Superimposition of Lineaments on Drainage Pattern with Existing Groundwater Potential Map}

Figure 6 displays the correlation of superimposition of lineaments on drainage pattern (Figure 6b) with existing groundwater potential map (Figure 6a). Where the area marked "A" shows effective communications between lineaments and drainage pattern (structurally control). It coincides with regions of high groundwater potential. This implies that the boreholes drilled within this location will be productive during dry season, since 
the aquifers are actively recharging. The remaining part of the map marked " $\mathrm{B}$ " are not structurally control which implies that, during the dry season there is a tendency that the aquifer will dry up or experience low yield, since the aquifer is not actively recharged. Generally, low yield experienced in boreholes are as a result of poor effective porosity, permeability and interconnectivity of the pore spaces of the surrounding host rocks. Therefore, when the streams and river tributaries are not structurally controlled, they will not be flowing parallel to the structural features. A situation that may result in low saturation of the aquifer system is inevitable due to ineffective communication between the structural features and the surface water.

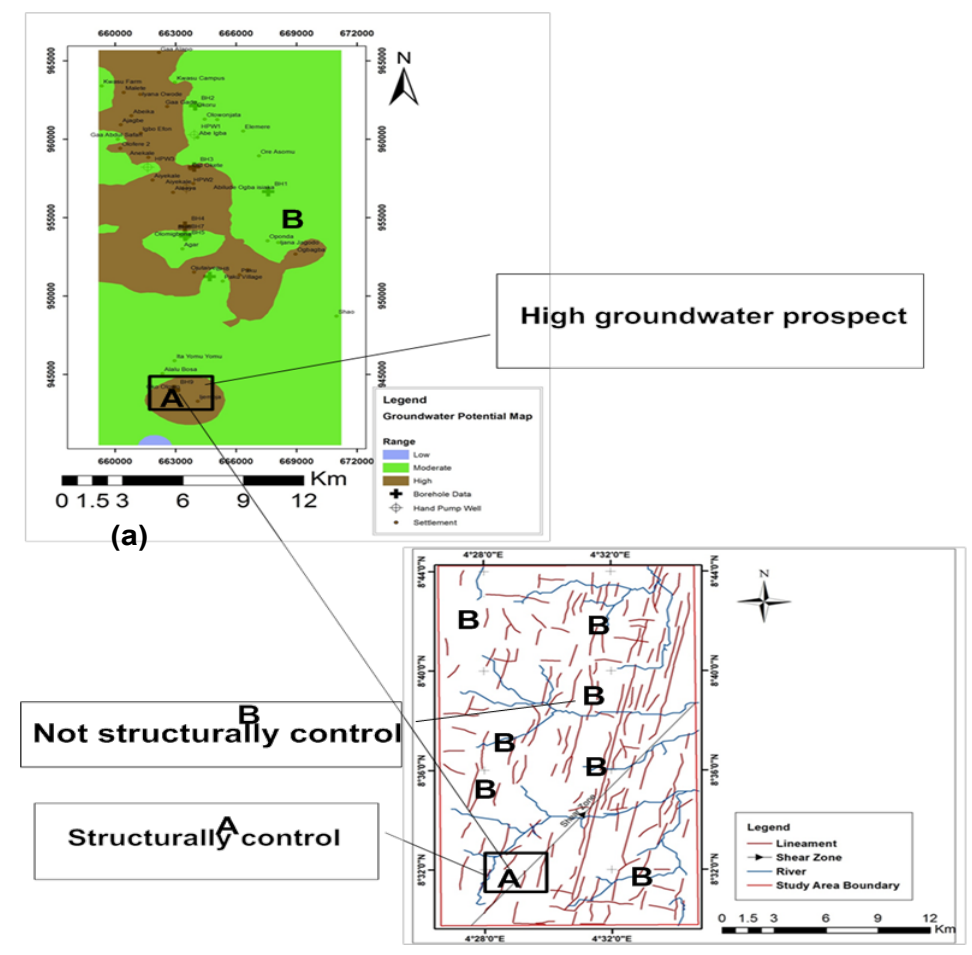

(b)

FIGURE 6. Correlation of superimposition of lineaments on drainage pattern with existing groundwater potential map of the study area.

\section{Conclusion}

It is concluded that the lineament and drainage pattern play a significant role in the groundwater development of this study location and may be responsible for the generally low groundwater prospect in the study area. The lineaments intersection results and the drainage pattern orientation explained the cause of failure/low yield of the wells/borehole in the area. This phenomenon is due to huge disagreement between the lineament and surface water flow direction. Most of the lineaments are in north-eastern and southwestern direction while the drainage orientation is in east west direction, arising from this, 
large number of the available structures do not interact effectively with the surface water and therefore liable to dry up in the dry season. Also, the minor and major rivers around the study area have been studied to be seasonal in nature. These will in no doubt affect the productivity of the aquifer system in a typical basement complex terrain. The groundwater potential map generated from VES results has a reasonable relationship with the results generated from the superimposition of the lineament and drainage system within the study area. In other words, the area with ineffective interaction between the lineament and drainage system showed low groundwater potential while area with reasonable interaction displayed moderate to high groundwater potential. North-western part, central part and some part of the southern region of the study area are characterized with high groundwater potential while the remaining part are characterized with moderate groundwater potential except small portion to the south-western part which is of low groundwater potential. The disagreement between the lineaments and drainage pattern has contributed to the low recharge rate of aquifers present within the rock units in the study area. It is therefore recommended that indiscriminate drilling of boreholes without recourse to available geophysical data should be discouraged as some of the wells are bound to fail or produce very low yield.

\section{References}

1. Olorunfemi MO. Voyage on the skin of the earth": a geophysical experience. In: Inaugural lecture series 211. 2007; 1-2.

2. Ilugbo SO, Adebiyi AD. Intersection of Lineaments for groundwater prospect analysis using satellite remotely sensed and aeromagnetic dataset around Ibodi, Southwestern Nigeria. International Journal of Physical Sciences. 2017, 12(23), 329-353.

3. Al-muqdadi SW, Merkel BJ. Interpretation of groundwater flow into fractured aquifer. International Journal of Geosciences. 2012, 3, 357-364.

4. Shrestha JN. Geophysical prospect for mineral deposit. Centre for Exploration Geophysics. 1977; 79-81.

5. Prabu P, Rajagopalan B. Mapping of lineaments for groundwater targeting and sustainable water resource management in hard rock hydrogeological environment using RS-GIS. Intech Open Science/Open Minds. 2013; 235-247.

6. Hydrogeology. https://link.springer.com/journal/volumesAndIssues/10040. Date accessed: 1996.

7. Bawallah MA, Aina AO, Ilugbo SO, Olufemi B, Olasunkanmi NK, Olaogun SO, Ajayi-Gidi IO. Modeling of groundwater potential using GIS and multi criteria decision analysis around Kwara State, Southwestern Nigeria. Journal of Applied Geology and Geophysics. 2018, 6(3), 58-67.

8. Olasehinde PI. An integrated geologic and geophysical exploration techniques for groundwater in the basement complex of west central part of Nigeria. Journal of Water Resources. 1999, 11, $46-49$.

9. Obaje NG. Geology and mineral resources of Nigeria. In: Lecture Notes in Earth Sciences. 2009; 219.

10. Remote sensing and GIS analysis of spatial distribution of fracture pattern in the Makran Accretionary Prism, Souteast Iran. https://scholarworks.gsu.edu/geosciences_theses/8/. Date accessed: 08/03/2007. 
11. Masound, A, Koike K. Tectonic architecture through Landsat-7 ETM+/SRTM DEM derived lineaments and relationship to the hydro-geologic setting in Siwa region, NW Egypt. Journal of African Earth Sciences. 2006, 45, 467-477.

12. Solomon S, Ghebreab W. Lineament characterization and their tectonic significance using Landsat TM data and field studies in the central highlands of Eritrea. Journal of African Earth Sciences. 2006, 46, 371-378.

13. Assessment of groundwater potential using integration of Landsat imagery and geophysical methods around Ibodi, Southwestern Nigeria. https://www.researchgate.net/scientificcontributions/2145296988_S_O_Ilugbo. Date accessed: 2014. 